\title{
Hexane fraction from the ethanolic extract of Sargassum serratifolium suppresses cell adhesion molecules via regulation of NF-KB and Nrf2 pathway in human umbilical vein endothelial cells
}

\author{
Wi-Gyeong Gwon', Sang-Gil Lee', Jae-Il Kim¹, Young-Mog Kim², Seon-Bong Kim² and Hyeung-Rak Kim*
}

\begin{abstract}
Sargassum serratifolium ethanolic extract has been known for strong antioxidant and anti-inflammatory properties. We prepared hexane fraction from the ethanolic extract of S. serratifolium (HSS) to improve biological activities. In this study, we investigated the effects of HSS on the inhibition of tumor necrosis factor (TNF)-a-induced monocyte adhesion to human umbilical vein endothelial cells (HUVECS). We found that HSS suppressed the production of cell adhesion molecules such as intracellular adhesion molecule-1 and vascular cell adhesion molecule-1 in TNF-a-induced HUVECS. Moreover, TNF-a-induced production of monocyte chemoattractant protein 1 and keratinocyte chemoattractant was inhibited by HSS treatment. HSS suppressed TNF-a-induced nuclear factor kappa B (NF-kB) activation via preventing proteolytic degradation of inhibitor KB-a. HSS induced the production of heme oxygenase 1 via translocation of Nrf2 into the nucleus in TNF-a-treated HUVECs. Overall, HSS alleviated vascular inflammation through the downregulation of NF-KB activation and the upregulation of Nrf2 activation in TNF-a-induced HUVECs. These results indicate that HSS may be used as therapeutic agents for vascular inflammatory disorders.
\end{abstract}

Keywords: Sargassum serratifolium, Vascular inflammation, Nuclear factor-kB, Adhesion molecule, Human umbilical vein endothelial cell

\section{Background}

Vascular inflammation has been known to play a key role in the progress of atherosclerosis, and enhanced monocyte adhesion to endothelial cells is believed to be one of the earliest events in atherogenesis (Packard and Libby 2008). Accumulating evidences have revealed that chronic inflammation plays a crucial role in the initiation and progression of atherosclerosis. Monocyte adhesion to endothelial cells is primarily mediated by several intracellular signaling events that lead to the elevated expression of endothelial adhesion molecules, including vascular cell adhesion molecule-1 (VCAM-1) and intracellular adhesion molecule-1 (ICAM-1) (Madge

\footnotetext{
* Correspondence: hrkim@pknu.ac.kr

${ }^{1}$ Department of Food Science and Nutrition, Pukyong National University, 45, Yongso-Ro, Nam-Gu, Busan 48513, Republic of Korea

Full list of author information is available at the end of the article
}

and Pober 2001; Rao et al. 2007). A vascular endothelium is a key target of tumor necrosis factor (TNF)- $\alpha$-induced inflammation, which promotes the expression of ICAM-1 and VCAM-1. Monocyte chemoattractant protein (MCP)-1 and keratinocyte chemoattractant (KC) have pivotal roles in recruiting monocytes to the lesion of dysfunctional endothelium. Excess chemokines are found in human atherosclerotic plaques and regulate the interaction between monocytes and vascular endothelial cells (Catalan et al. 2015). Taking these evidences, inhibition of adhesion molecules and chemokines may be a promising approach to prevent atherosclerosis by blocking monocyte invasion to the vascular inflammatory lesion.

An accumulative evidence suggests that TNF- $\alpha$, a pleiotropic pro-inflammatory cytokine in the inflammatory cascade, involves in a critical role in vascular inflammation and the subsequent progress of atherosclerosis 
(Madge and Pober 2001). TNF- $\alpha$ induces the production of reactive oxygen species (ROS) by the activation of membrane-bound nicotinamide adenine dinucleotide phosphate (NADPH) oxidase in endothelium (Kleinbongard et al. 2010). Excess ROS produced by TNF- $\alpha$ stimulate the phosphorylation of the inhibitor $k B$ kinase (IKKs) complex, leading to the proteasomal degradation of phosphorylated IкB-a. Thus, free NF-kB dissociated from IкB is translocated into the nucleus and binds to the cis-acting element to regulate the expression of adhesion molecules in endothelium (Huang et al. 2018). Thus, approaches to regulate endothelial activation are potential strategies to prevent atherosclerosis through the suppression of vascular inflammation.

Sargassaceae family is consumed as food or traditional medicine in Korea and China and various bioactive compounds have been identified as meroterpenoids, phlorotannins, fucoxanthins, and fucosterols (Liu et al. 2012). Sargassum serratifolium (C. Agardh), a marine brown alga, is broadly distributed throughout the Korean and Japanese coasts. Recently, we reported that ethanolic extract of S. serratifolium showed antioxidant and antiinflammatory activities and active compounds were identified as sargahydroquinoic acid (SHQA), sargachromenol (SCM), and sargaquinoic acid (SQA) (Joung et al. 2017; Lim et al. 2018; Oh et al. 2016). Moreover, SCM and SQA isolated from the ethanolic extract of S. serratifolium showed a potent anti-inflammatory activity in LPS-stimulated macrophages and antiatherogenic activities in TNF- $\alpha$-treated human umbilical vein endothelial cells (HUVECs), respectively (Gwon et al. 2017; Gwon et al. 2015; Joung et al. 2015). We prepared a meroterpenoid-rich fraction from the ethanolic extract of $S$. serratifolium (MES) by removing salts and water-soluble saccharides, and the combined amount of SHQA, SCM, and SQA was estimated to be $46 \mathrm{~g}$ in $100 \mathrm{~g}$ of MES (Gwon et al. 2018; Kwon et al. 2018). To further concentrate active compound in MES, we fractionated MES with $n$-hexane, and resulting $n$-hexane fraction from the ethanolic extract of S. serratifolium (HSS) contained $64 \%$ of three components in HSS. For a better understanding of pharmacological actions of HSS, we examined the vascular anti-inflammatory actions of HSS in TNF- $\alpha$-stimulated HUVECs.

\section{Methods \\ Reagents}

Endothelial cell growth medium (EGM-2), growth supplements, and primary cultured HUVEC were obtained from Lonza (Walkersville, MD, USA). CellTiter ${ }^{96} \mathrm{AQ}_{\text {ue- }}$ ous One Solution Cell Proliferation assay kit and reverse transcriptase were purchased from Promega (Madison, WI, USA). Enhanced chemiluminescence (ECL) detection kit was purchased from GE Healthcare Bio-Science (Piscataway, NJ, USA). QIAzol lysis reagent was purchased from Quiagen (Valencia, CA). $2^{\prime}, 7^{\prime}$-Bis(2-carboxyethyl)-5(6)-carboxyfluorescein acetoxy-methyl ester (BCECF-AM), Alexa Fluor ${ }^{\circ}$ 488-conjugated secondary antibody, 4',6-diamidino-2-phenylindole (DAPI), and dual luciferase assay kits were purchased from Invitrogen (Carlsbad, CA, USA). $2^{\prime}, 7^{\prime}$-dichlorofluorescin diacetate (DCFH-DA), dimethyl sulfoxide (DMSO), and phenylmethylsulfonyl fluoride (PMSF) were obtained from Sigma-Aldrich Corporation (St. Louis, MO, USA). The antibodies against ICAM-1, VCAM-1, and HO- 1 were obtained from Abcam (Cambridge, UK). pIKK- $\beta$, IKK- $\beta$, pIkB- $\alpha$, and IкB- $\alpha$ were purchased from Cell Signaling (Danvers, MA, USA). NF- $\kappa B$, GAPDH, PARP, $\beta$-actin, Nrf2, and secondary antibody were purchased from Santa Cruz Biotechnology (Santa Cruz, CA, USA).

\section{Preparation of $n$-hexane fraction from the ethanolic extract of S. serratifolium}

S. serratifolium was collected along the coast of Busan, South Korea, in May 2015. Specimen identity was confirmed by an algal taxonomist (C.G. Choi), at the Department of Ecological Engineering, Pukyong National University, Republic of Korea, and a voucher specimen was deposited in Marine Brown Algae Resources Bank, Republic of Korea (TC18835). Collected sample was air-dried and ground. One and a half kilograms of dried sample was extracted twice with $70 \%(v / v)$ ethanol (6 $\mathrm{L}$ each time) at $70{ }^{\circ} \mathrm{C}$ for $3 \mathrm{~h}$. The combined extract was filtered through the ultrafiltration unit (MWCO, $50 \mathrm{kDa})$ and concentrated until the lipophilic fraction was separated from salt water. The lipophilic fraction was concentrated by a rotary vacuum evaporator (Eyela N3010, Tokyo, Japan) at $45^{\circ} \mathrm{C}$ after washing three times with 10 times volume of D.W. (meroterpenoid-rich extract from S. serratifolium, MES). For further concentrate active component in MES, the extract was resuspended in water/EtOH $(1 v / v)$ and partitioned with $n$-hexane, ethyl acetate, $n$-butanol, and D.W. The $n$-hexane fraction which showed the highest anti-inflammatory activity against LPS-induced RAW 264.7 cells was concentrated by a rotary vacuum evaporator and kept at $-20^{\circ} \mathrm{C}$ for this study. From $1.5 \mathrm{~kg}$ of dried sample, $80 \mathrm{~g}$ of the HSS was obtained. Isolation and quantification of SHQA, SCM, and SQA were performed according to the method described previously (Azam et al. 2017; Joung et al. 2017). Quantification of SHQA, SCM, and SQA in HSS was performed with the method described previously (Joung et al. 2017), and the contents of SHQA, SCM, and SQA in 100 $\mathrm{g}$ of HSS were estimated to be $52.4 \pm 3.3,8.26 \pm 0.82$, and $3.0 \pm 0.21 \mathrm{~g}$, respectively, as determined by calibration curves (Lim et al. 2019). 


\section{Cell culture and treatment}

HUVECs were grown in EGM-2 medium with $2 \%$ fetal bovine serum (FBS) and endothelial growth supplement and used between passage 3 and 6. HUVECs were cultured in $100-\mathrm{mm}$ dishes at a concentration of $5 \times 10^{5}$ cells/dish in EGM-2 medium. Human monocytic THP-1 cells (KCLB, Seoul, Korea) were maintained in RPMI-1640 containing 10\% FBS (GIBCO, Grand Island, NY, USA). Both cells were maintained at $37{ }^{\circ} \mathrm{C}$ in a humidified chamber containing $5 \% \mathrm{CO}_{2}$ and $95 \%$ air. HSS was dissolved in dimethyl sulfoxide (DMSO), and the final DMSO concentration in all assays was adjusted to $0.1 \%$.

\section{Measurement of cell viability}

The cytotoxicity of HSS was determined by MTS assay. HUVECs were pretreated with a serial dilution of HSS for $1 \mathrm{~h}$ and then stimulated with TNF- $\alpha(10 \mathrm{ng} / \mathrm{mL})$ for an additional $24 \mathrm{~h}$, except for control wells. MTS solution with fresh medium was added to each well. After $1 \mathrm{~h}$, the absorbance was measured at $490 \mathrm{~nm}$ with a microplate reader (GloMax Multi Detection System, Promega).

\section{Measurement of MCP-1 and KC by ELISA}

Cells were inoculated in 12-well plates at a density of $1.5 \times 10^{5}$ cells/well and pretreated with $2.5,5.0$, and $10 \mu \mathrm{g} / \mathrm{mL}$ of HSS for $1 \mathrm{~h}$ prior to TNF- $\alpha(10 \mathrm{ng} / \mathrm{mL})$ stimulation for $24 \mathrm{~h}$. Culture medium was collected after centrifugation at $2000 \times g$ for $10 \mathrm{~min}$ and stored at $-80^{\circ} \mathrm{C}$ until testing. Levels of MCP-1 and $\mathrm{KC}$ in culture media were quantitively determined by ELISA kit according to the manufacturer's instruction.

\section{Cell-based enzyme-linked immunosorbent assay}

The expression of ICAM-1 and VCAM-1 on the surface of HUVECs was assessed using ELISA, as previously described (Gwon et al. 2015). Briefly, HUVECs were pretreated with HSS $(2.5,5.0$, and $10.0 \mu \mathrm{g} / \mathrm{mL})$ for $1 \mathrm{~h}$ followed by TNF- $\alpha$ treatment $(10 \mathrm{ng} / \mathrm{mL})$ for $6 \mathrm{~h}$. The cells were then fixed by $1 \%$ paraformaldehyde and then blocked with $2 \%$ bovine serum albumin (BSA) at room temperature. Subsequently, the cells were incubated with mouse anti-human ICAM-1 or VCAM-1 antibodies for $2 \mathrm{~h}$ and washed with phosphate-buffered saline (PBS). Cells were incubated with the horseradish peroxidase (HRP)-conjugated secondary antibody and washed, followed by peroxidase substrate solution. The absorbance at $490 \mathrm{~nm}$ was measured using a microplate reader (Glomax Multi Detection System, Promega).

\section{Reverse transcription-polymerase chain reaction}

The mRNA levels of ICAM-1 and VCAM-1 in HUVECs were determined using RT-PCR. Total RNA was extracted from HUVECs by QIAzol reagent according to the manufacturer's instructions. Five micrograms of total
RNA were used for reverse transcription using oligo$\mathrm{dT}$-adaptor primer and superscript reverse transcriptase. PCR was performed with the gene-specific primers (Table 1). PCR products were observed by electrophoresis in agarose gels and visualized with UV light after staining with ethidium bromide. Densitometric analysis was performed using EZ-Capture II (ATTO and Rise Co., Tokyo, Japan) and CS analyzer (ver. 3.00 software, ATTO).

\section{Preparation of cytosolic and nuclear extracts}

HUVECs were seeded in a culture dish at a density of $6 \times 10^{5}$ cells/dish. Cultured cells were pretreated with $0,2.5,5.0$, and $10.0 \mu \mathrm{g} / \mathrm{mL}$ of HSS for $1 \mathrm{~h}$ and stimulated with TNF- $\alpha$ for $30 \mathrm{~min}$. Separation of cytosolic and nucleus fraction was performed as previously described (Gwon et al. 2015).

\section{Western blot analysis}

HUVECs pretreated with $0,2.5,5.0$, and $10.0 \mu \mathrm{g} / \mathrm{mL}$ HSS for $1 \mathrm{~h}$ were stimulated with TNF- $\alpha(10 \mathrm{ng} / \mathrm{mL})$ at times indicated in the figure legends. Cells were washed twice with cold PBS and lysed with lysis buffer on ice for $20 \mathrm{~min}$. After centrifugation at $12,000 \times \mathrm{g}$ for $20 \mathrm{~min}$, the protein concentrations of the supernatants were determined and an equal amount of protein was loaded on sodium dodecyl sulfate-polyacrylamide gel electrophoresis (SDS-PAGE) for protein separation. The specific procedure for Western blot is described in our previous paper (Gwon et al. 2015). The antibodies against ICAM-1, VCAM-1, HO- 1 , pIKK- $\beta$, IKK- $\beta$, pIкB- $\alpha$, and I $\mathrm{B}-\alpha$ were diluted to $1 / 3000$, and those against NF- $\mathrm{KB}$, glyceraldehyde 3-phosphate dehydrogenase (GAPDH), poly (ADP-ribose) polymerase (PARP), $\beta$-actin, and Nrf2 were diluted to $1 / 1000$ with Tris-buffered saline.

\section{Determination of intracellular ROS levels}

The levels of intracellular ROS in HUVECs were measured using fluorescent probe DCFH-DA. HUVECs in the 96-well black plate were pretreated with $0,2.5$, 5.0, and $10.0 \mu \mathrm{g} / \mathrm{mL}$ HSS for $1 \mathrm{~h}$ and then incubated

Table 1 Primer sequences for RT-PCR

\begin{tabular}{|c|c|c|}
\hline Primer & & Sequence \\
\hline \multirow[t]{2}{*}{ ICAM-1 } & Forward & 5'-GAGATCACCTGGAGCCAAT-3' \\
\hline & Reverse & 5'-CCTCTGGCTTCGTCAGAATC-3' \\
\hline \multirow[t]{2}{*}{ VCAM-1 } & Forward & 5'-GGAAGCCGATCACAGTCAAG-3' \\
\hline & Reverse & 5'-GCATTTCCAGAAAGGTGCTG-3' \\
\hline \multirow[t]{2}{*}{$\mathrm{HO}-1$} & Forward & 5'-AGTCTTCGCCCCTGTCTACT-3' \\
\hline & Reverse & 5'-GGGGCAGAATCTTGCACTTT-3' \\
\hline \multirow[t]{2}{*}{ GAPDH } & Forward & 5'-ACCACAGTCCATGCCATCAC-3' \\
\hline & Reverse & 5'-TCCACCACCCTGTTGCTGTA-3' \\
\hline
\end{tabular}


with $20 \mu \mathrm{M}$ DCFH-DA for $30 \mathrm{~min}$. The cells were stimulated with TNF- $\alpha(10 \mathrm{ng} / \mathrm{mL})$ for $1 \mathrm{~h}$. The fluorescence levels were determined using a fluorescence microplate reader (Em $485 \mathrm{~nm}$ and Ex $528 \mathrm{~nm}$ ).

\section{Immunofluorescence analysis}

To assess the translocation of NF- $k B$, HUVECs were grown on 8-well chamber slides (SPL Life Sciences Co., Gyeonggi-do, Korea) and stimulated with TNF- $\alpha$ $(10 \mathrm{ng} / \mathrm{mL})$ for $30 \mathrm{~min}$ after HSS pretreatment for $1 \mathrm{~h}$. The cells were fixed with $4 \%$ paraformaldehyde in PBS for $15 \mathrm{~min}$. After washing with PBS, the cells were permeabilized with $0.5 \%$ Triton X-100 in PBS for 10 min. After blocking with $3 \%$ BSA/PBS for $30 \mathrm{~min}$, cells were incubated with an anti-NF-kB antibody for $2 \mathrm{~h}$ followed by Alexa Fluor ${ }^{\circ} 488$-conjugated secondary antibody for $1 \mathrm{~h}$. Cells were stained with $2 \mu \mathrm{g} / \mathrm{mL}$ DAPI and images were captured using a confocal microscope.

\section{Statistical analysis}

Data are expressed as the means \pm standard deviations (SDs). Data analysis was performed using ANOVA followed by the Bonferroni test. $P$ values $<0.05$ were considered statistically significant. SPSS for Windows, version 10.07 (SPSS Inc., Chicago, IL, USA) was used for all analyses.

\section{Results}

Inhibitory activity of EtOH extract and its solvent-soluble fractions on ICAM-1 and VCAM-1 production

In order to evaluate the vascular anti-inflammatory potential of $S$. serratifolium, the $\mathrm{EtOH}$ extract and its solvent-soluble fractions were tested using TNF- $\alpha-$ treated HUVECs. Inhibitory effects $\left(\mathrm{IC}_{50}\right)$ of these fractions on the adhesion molecules were determined with non-toxic concentration by Western blot using TNF$\alpha$-stimulated HUVECs. As shown in Table 2, $\mathrm{IC}_{50}$ values of $\mathrm{EtOH}, \mathrm{HSS}$, and EtOAc for the inhibition of ICAM-1

Table 2 Inhibitory activity of HSS and its solvent-soluble fractions on the expression of ICAM-1 and VCAM-1 in TNF-astimulated HUVECS

\begin{tabular}{|c|c|c|c|}
\hline \multirow[t]{2}{*}{ Fractions } & \multicolumn{2}{|c|}{$\mathrm{IC} 50(\mu \mathrm{g} / \mathrm{mL})^{\mathrm{a}}$} & \multirow{2}{*}{$\begin{array}{l}\text { Yields } \\
(\%)^{c}\end{array}$} \\
\hline & $\overline{\text { ICAM}^{-b}} 1^{\mathrm{b}}$ & VCAM- $1^{\mathrm{b}}$ & \\
\hline Ethanolic extract & $7.25 \pm 0.53$ & $6.67 \pm 0.31$ & $100 \pm 5.2$ \\
\hline n-Hexane & $4.55 \pm 0.52$ & $3.61 \pm 0.22$ & $66.1 \pm 4.3$ \\
\hline Ethyl acetate & $2.29 \pm 0.13$ & $4.53 \pm 0.28$ & $9.23 \pm 1.2$ \\
\hline n-Butanol & $\geq 100$ & $\geq 100$ & $17.5 \pm 1.9$ \\
\hline Water & $\geq 100$ & $\geq 100$ & $8.12 \pm 1.4$ \\
\hline
\end{tabular}

a $\mathrm{C} 50$ is calculated to be concentrations with a half-maximal expression of ICAM- 1 and VCAM- 1 in TNF-a-stimulated HUVECs

${ }^{\mathrm{b}}$ The expression of levels of ICAM- 1 and VCAM-1 were determined with Western blot

${ }^{c}$ Yield is showing the amount of each fraction in $100 \mathrm{~g}$ of ethanolic extract were estimated to be $7.25 \pm 0.53(\mu \mathrm{g} / \mathrm{mL}), 4.55 \pm 0.52$ $(\mu \mathrm{g} / \mathrm{mL})$, and $2.29 \pm 0.13(\mu \mathrm{g} / \mathrm{mL})$, respectively. $\mathrm{IC}_{50}$ values of EtOH, HSS, and EtOAc for the inhibition of VCAM-1 were also determined to be $6.67 \pm 0.31(\mu \mathrm{g} / \mathrm{mL})$, $3.61 \pm 0.22(\mu \mathrm{g} / \mathrm{mL})$, and $4.53 \pm 0.28(\mu \mathrm{g} / \mathrm{mL})$, respectively. With $n$-Hexane fractionation, HSS showed 1.6-fold and 1.8-fold stronger inhibitory activity on the production of ICAM-1 and VCAM-1, respectively, than MES. However, the $n$-butanol and $\mathrm{H}_{2} \mathrm{O}$ fraction were not inhibited ICAM-1 and VCAM-1 production. Although EtOAc fraction showed selectively higher inhibitory activity for ICAM-1 production, active compounds in the EtOAc were not identified. Thus, we investigated molecular mechanisms of HSS on the inhibition of vascular inflammation using TNF- $\alpha$-stimulated HUVECs.

\section{HSS inhibits the production of TNF-a-induced adhesion molecules}

To examine the cytotoxicity of HSS, the viability of HUVECs was measured by the MTS assay. HUVECs were cultured in 96-well microplates for $24 \mathrm{~h}$ and pretreated with various concentrations of HSS (2.5, 5.0, and $10.0 \mu \mathrm{g} / \mathrm{mL}$ ) followed by TNF- $\alpha$-stimulation. The viability was not influenced up to $10.0 \mu \mathrm{g} / \mathrm{mL}$ of HSS in HUVECs (Fig. 1a). Since monocyte adhesion to HUVECs is critically regulated by ICAM-1 and VCAM-1, we assessed the production of ICAM-1 and VCAM-1 protein using Western blot. The expression levels of both adhesion molecules were remarkably elevated in TNF- $\alpha$-treated HUVECs (Fig. 1b). Pretreatment of HSS at $5.0 \mu \mathrm{g} / \mathrm{mL}$ notably reduced the production of ICAM-1 and VCAM-1 by $66.1 \%$ and $52.7 \%$, respectively, which shows stronger inhibitory activity for adhesion molecules than $\mathrm{EtOH}$ extract. To further investigate the effect of HSS on ICAM-1 and VCAM-1 mRNA expression, RT-PCR was performed. Our data showed that HSS dose-dependently suppressed mRNA expression of both adhesion genes in TNF- $\alpha$-treated HUVECs (Fig. 1c). Furthermore, the result of cell-based ELISA assay showed that HSS suppressed the expression of ICAM-1 and VCAM- 1 in TNF- $\alpha$-treated HUVECs in a dosedependent manner (Fig. 1d). These data indicate that the HSS-mediated downregulation of adhesion molecules in TNF- $\alpha$-treated endothelium is primarily attributable to their transcriptional regulation.

\section{HSS suppresses TNF- $a$-induced chemokine production}

Recruitment of monocytes to endothelium is largely regulated by chemokines, including MCP-1 and KC. As shown in Fig. 2, exposure of TNF- $\alpha$ to HUVECs for $6 \mathrm{~h}$ enhanced the production of MCP-1 (Fig. 2a) and KC (Fig. 2b). HSS pretreatment as low as $2.5 \mu \mathrm{g} / \mathrm{mL}$ inhibited TNF- $\alpha$-induced production of both chemokines. Pretreatment with $10 \mu \mathrm{g} / \mathrm{mL}$ HSS decreased the production 

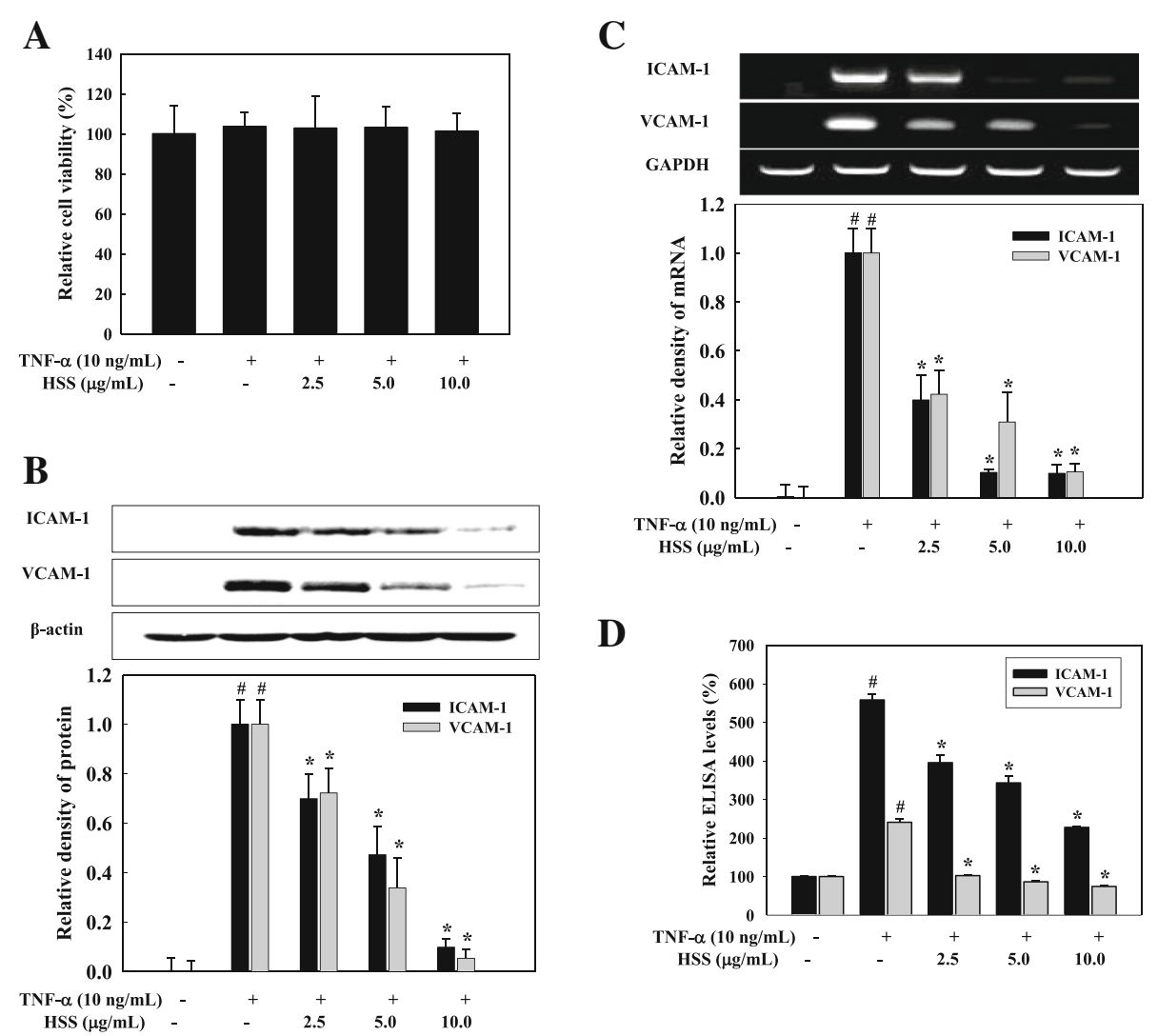

Fig. 1 Effect of HSS on the production of TNF-a-induced ICAM-1 and VCAM-1 expression in HUVECs. a Cytotoxic effect of HSS was measured by MTS assay. $\mathbf{b}$ Cells pretreated with the indicated concentration of HSS for $1 \mathrm{~h}$ were stimulated with TNF- $\mathrm{a}$ for $6 \mathrm{~h}$. Equal amounts of total protein were separated by $10 \%$ SDS-PAGE. The expression of ICAM-1, VCAM-1, and $\beta$-actin was examined by Western blot using corresponding antibodies. $\mathbf{c}$ Cells pretreated with the indicated concentration of HSS for $1 \mathrm{~h}$ were stimulated with TNF-a for $6 \mathrm{~h}$, and total RNA was prepared for RT-PCR. $\mathbf{d}$ Fixed cells with $1 \%$ paraformaldehyde were analyzed by ELISA for the cell surface expression of ICAM-1 and VCAM-1. The values are shown as the means \pm SDs from three independent experiments. ${ }^{\#} P<0.05$ represents significant differences versus the non-treated group. ${ }^{*} P<0.05$ represents significant differences versus the TNF-a-only group

of both chemokines to control level. This result indicates that HSS suppresses recruitment of monocytes to endothelium by inhibition of chemokine production.

\section{HSS inhibits TNF-a-induced NF-KB activation in HUVECs}

To assess whether HSS inhibits the translocation of NF- $\mathrm{kB}$ into the nucleus, microscopic analysis was performed. Confocal observation indicated that NF- $\mathrm{kB} / \mathrm{p} 65$ was predominantly localized in the perinuclear compartment under unstimulated condition. With TNF- $\alpha$ treatment, most of cytoplasmic NF- $\mathrm{kB} / \mathrm{p} 65$ translocated to the nucleus (Fig. 3a). However, HSS pretreatment at $10 \mu \mathrm{g} / \mathrm{mL}$ markedly inhibited the NF- $\mathrm{kB} / \mathrm{p} 65$ translocation into the nucleus. For further investigating the molecular mechanism underlying HSS-mediated inhibition of NF- $\mathrm{kB} / \mathrm{p} 65$ translocation in TNF- $\alpha$-stimulated cells, we examined the phosphorylation of inhibitor $\mathrm{kB}$ kinase (IKK) $-\beta$ and IкB- $\alpha$ that are associated with the NF- $\kappa B$ activation. TNF- $\alpha$ markedly caused the phosphorylation of IKK- $\beta$ and led to IкB- $\alpha$ phosphorylation, whereas HSS dose-dependently inhibited the phosphorylation of both proteins (Fig. $3 \mathrm{~b}$ ). The phosphorylation level of cytosolic IкB- $\alpha$ at $10 \mu \mathrm{g} / \mathrm{mL}$ HSS was comparable to the control group possibly due to the inhibitory effect of HSS on the phosphorylation IKK- $\beta$ (Fig. 3b). In addition, TNF- $\alpha$-mediated increase in NF- $\mathrm{kB}$ protein level in the nucleus was dose-dependently decreased by HSS treatment (Fig. 3b). These results suggest that the HSS-mediated inhibition of adhesion molecules and chemokines are largely regulated by the NF- $\mathrm{kB}$ pathway in the TNF- $\alpha$-stimulated cells. TNF- $\alpha$ activates the membrane-bound NADPH oxidase in endothelium which stimulates ROS production, a second messenger for NF-kB activation (Kim et al. 2008). We examined the inhibitory effects of the HSS on intracellular ROS accumulation in TNF- $\alpha$-treated HUVECs. TNF- $\alpha$-induced ROS was markedly reduced by HSS pretreatment (Fig. $3 \mathrm{C}, P<0.05$ ), indicating that intrinsic antioxidant 

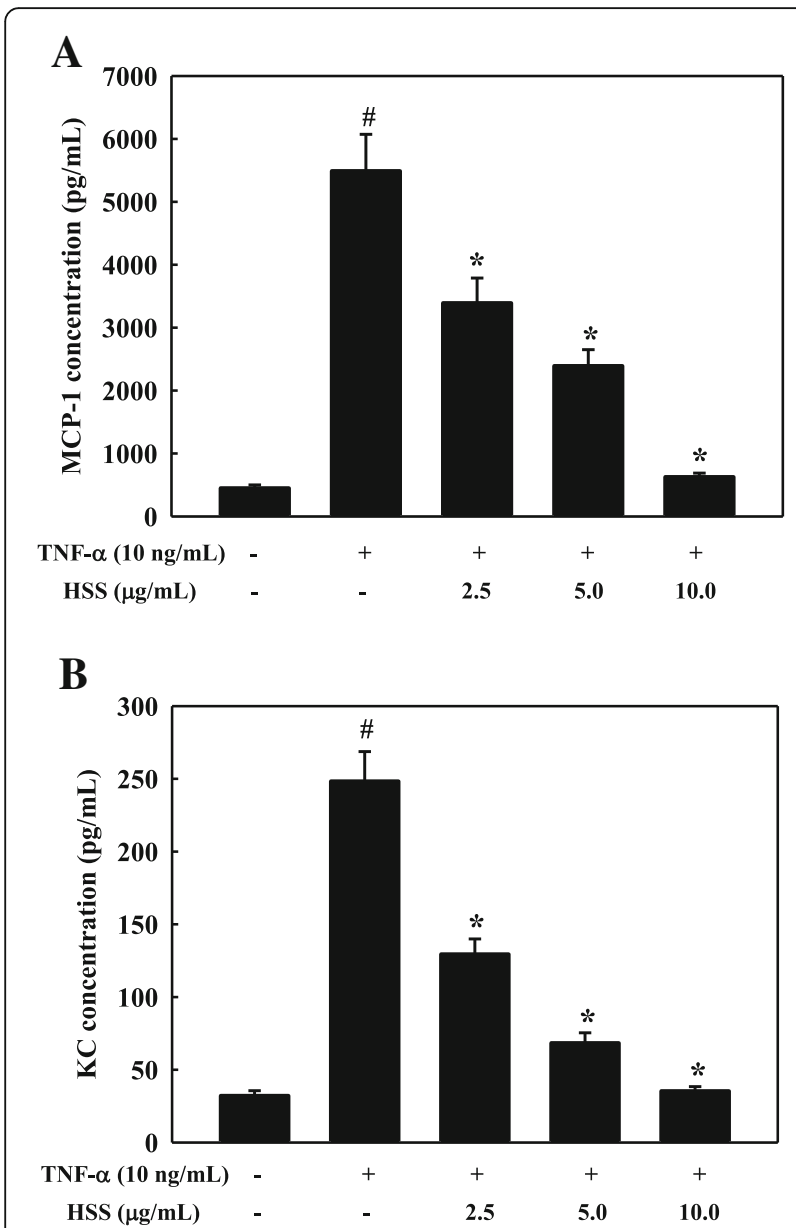

Fig. 2 Effect of HSS on the production of MCP-1 and KC in TNF- induced HUVECs. Cells pretreated with the indicated concentration of HSS for $1 \mathrm{~h}$ were stimulated with TNF-a for $24 \mathrm{~h}$. The levels of MCP-1 (a) and KC (b) were examined by ELISA. The values are shown as the means \pm SDs from three independent experiments. ${ }^{\#} P<0.05$ represents significant differences versus the control group. ${ }^{*} P<0.05$ represents significant differences versus the TNF-a-only group

activity of HSS is associated with inhibiting NF- $\mathrm{kB}$ activation through scavenging ROS induced by TNF- $\alpha$ treatment.

\section{HSS induces HO-1 production through Nrf2 activation}

Increased endogenous $\mathrm{HO}-1$ provides cellular protection against TNF- $\alpha$-induced ROS. Therefore, we determined the effect of HSS on the production of HO-1 protein and mRNA by Western blot and RT-PCR, respectively. HSS treatment caused an increased production of HO-1 protein and mRNA in a dose-dependent manner (Fig. 4a). We further determined the effect of HSS on the production of Nrf2, a key regulator of the HO-1 expression. As shown in Fig. 4b, HSS induced the production of Nrf2 determined by Western blot in TNF- $\alpha$-induced cells. These results implicate that HSS suppresses vascular inflammation through the induction of HO-1 via Nrf2 activation in TNF- $\alpha$-treated HUVECs.

\section{Discussion}

Our previous study reported that the ethanolic extract of S. serratifolium suppressed the production of vascular inflammatory proteins in serum and aorta tissue in high cholesterol diet-fed mice. The anti-atherogenic components in the extract were identified as SHQA, SCM, and SQA which showed strong anti-inflammatory and antioxidant activities (Gwon et al. 2018; Lim et al. 2019). The quantification data suggest that the contents of SHQA, SCM, and SQA in $100 \mathrm{~g}$ of meroterpenoid-rich extract from $S$. serratifolium (MES) were estimated to be $37.6 \pm 2.1, \quad 6.23 \pm 0.36$, and $1.89 \pm 0.10 \mathrm{~g}$, respectively (Kwon et al. 2018). To obtain a higher concentration of meroterpenoids from MES, we fractionated MES with $n$-hexane and the content of each component in HSS was comprised to be $52.4 \pm 3.3 \mathrm{~g}$ for SHQA, $8.26 \pm 0.82 \mathrm{~g}$ for SCM, and $3.0 \pm 0.21$ for SQA as determined by calibration curves (Lim et al. 2019). In the present study, we found that HSS showed a higher capacity for the suppression of ICAM-1, VCAM-1, and MCP-1 expression compared with MES. HSS suppressed the TNF- $\alpha$-induced NF- $\mathrm{kB}$ activation by blocking ІкB- $\alpha$ degradation. Additionally, HSS alleviated vascular inflammation by the production of HO-1 via Nrf2 activation. To our knowledge, this is in vitro evidence that HSS is a potent anti-inflammatory agent to alleviate vascular inflammation and to improve endothelial dysfunction.

Adhesion of circulating monocytes to vascular endothelium is an initial step in triggering vascular inflammation leading to atherosclerosis (Madge and Pober 2001). Pro-inflammatory stimuli, such as TNF- $\alpha$ exposure, initiate the expression of adhesion molecules that stimulate the attachment of circulating lymphocytes and monocytes to endothelium (Packard and Libby 2008). In this respect, the adhesion molecules such as VCAM-1 and ICAM-1 are well-known vascular inflammatory markers, which are related to tight adhesion of monocytes in atherosclerotic lesion of the endothelium (Packard and Libby 2008). Both adhesion molecules are largely produced in advanced human coronary atherosclerotic plaque and in experimental atherosclerosis animals (Catapano et al. 2017; Nallasamy et al. 2014). Our results implied that HSS blocked the TNF- $\alpha$-induced endothelial production of VCAM-1 and ICAM-1in HUVECs. These data indicate that the vascular anti-inflammatory action of HSS on TNF- $\alpha$-treated cells is mainly regulated by suppressing the production of adhesion molecules. Specifically, the current findings indicate that the HSS-mediated decline of adhesion molecules is closely associated with transcriptional regulation of ICAM-1 and VCAM-1 mRNA expression in TNF- $\alpha$-treated HUVECs. 


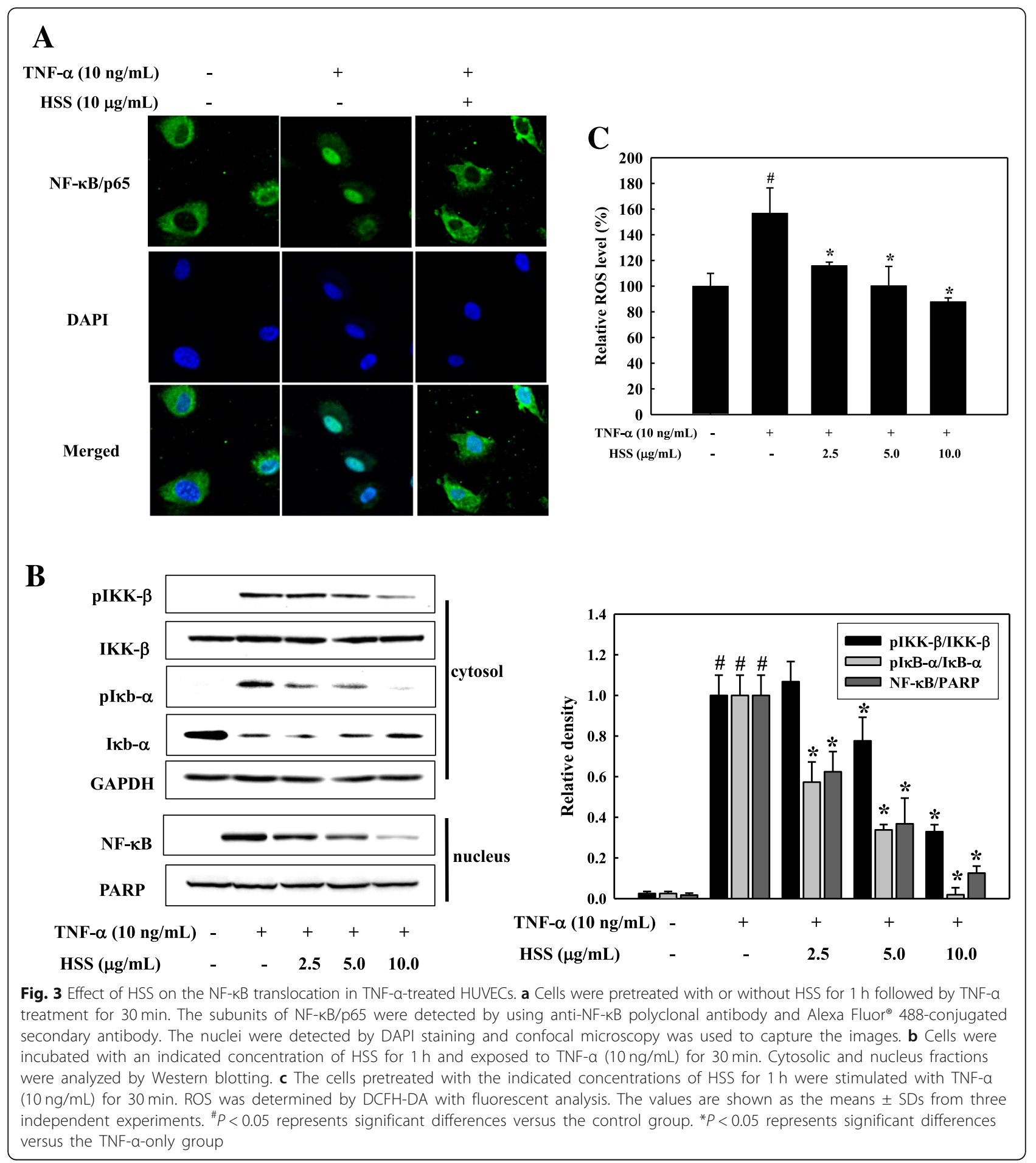

Chemokine produced by activated endothelium play pivotal roles for chemotactic attachment of circulating monocytes in the intima of the blood vessel. Chemokine stimulates sturdy adhesion of infiltrated monocytes to vascular endothelium which is a noticeable pathological mark in the early stage of atherogenesis (Chen et al. 2004). Accumulating evidence demonstrated that local overexpression of MCP-1 in vascular tissues promotes cooperation of monocytes/macrophages and formation of atherosclerotic lesion (Namiki et al. 2002). Chemokine $\mathrm{KC}$ is identified as the first chemokine responsible for monocyte arrest on early atherosclerotic lesion (Huo et al. 2001). KC stimulates monocyte adhesion in carotid arteries in the early atherosclerotic 


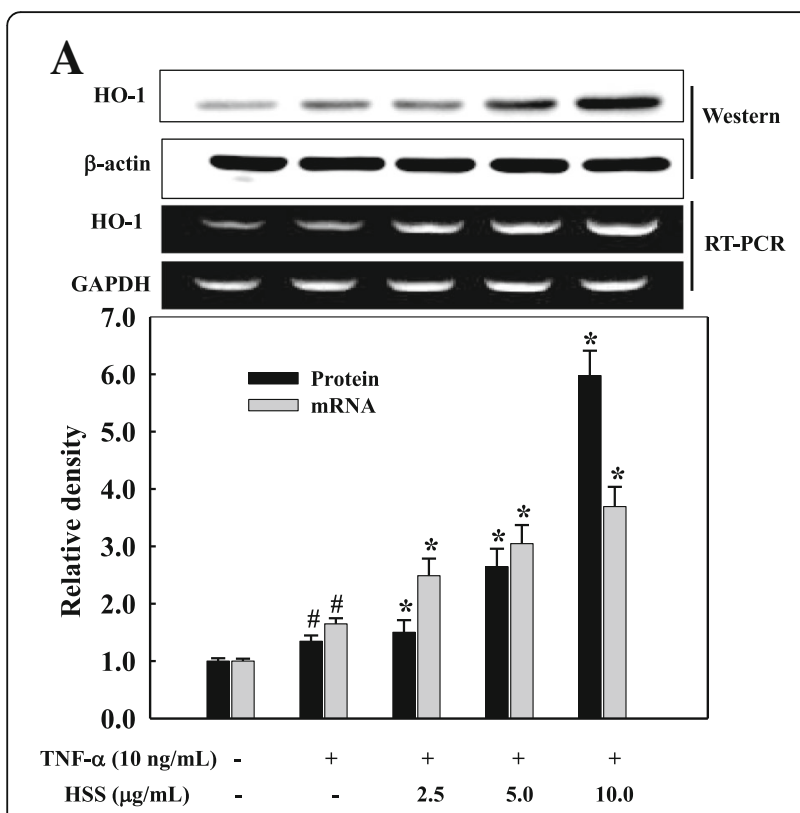

B
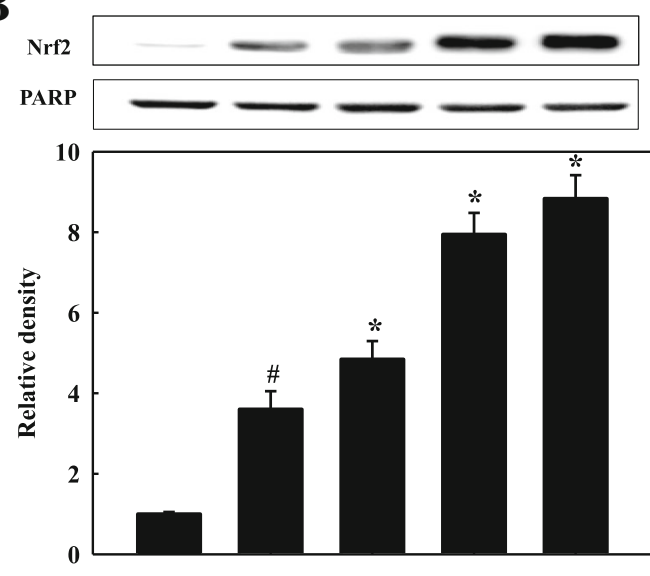

TNF- $\alpha(10 \mathrm{ng} / \mathrm{mL})$ $\operatorname{HSS}(\mu \mathrm{g} / \mathrm{mL})$

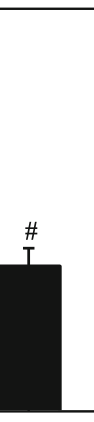

-

2.5

Fig. 4 Effect of HSS on HO-1 production and Nrf2 activation in TNFa-induced HUVECs. a Cells pretreated with the indicated concentration of HSS for $1 \mathrm{~h}$ were stimulated with TNF-a for $16 \mathrm{~h}$ (RT-PCR) or $24 \mathrm{~h}$ (Western blot). $\mathbf{b}$ Cells pretreated with the indicated concentration of HSS for $1 \mathrm{~h}$ were stimulated with TNF-a for $30 \mathrm{~min}$. The proteins were analyzed by Western blotting using corresponding antibodies. The values are shown as the means \pm SDs from three independent experiments. ${ }^{\#} P<0.05$ represents significant differences versus the control group. ${ }^{*} P<0.05$ represents significant differences versus the TNF-a-only group

lesion in mice (Huo et al. 2001). Both MCP-1 and KC are crucial chemokines to the progression of atherosclerosis, due to their abilities to recruit monocytes to the intima of the blood vessel (Chen et al. 2004). In this study, HSS inhibited the TNF- $\alpha$-induced production of MCP-1 and KC in TNF- $\alpha$-treated HUVECs. These results suggest that the anti-inflammatory action of HSS on TNF- $\alpha$-induced endothelium is mediated at least partially by inhibition of chemokine production.

$\mathrm{NF}-\mathrm{kB}$ is an essential transcription factor associated with the expression of adhesion molecules and chemokines (Huang et al. 2018). As discussed above, adhesion of monocyte to endothelium is stimulated through adhesion molecules and chemokines, including ICAM-1, VCAM-1, MCP-1, and KC in endothelial cells (De Filippo et al. 2008). The expression of these molecules is increased by NF-kB activation. In unstimulated conditions, NF- $\mathrm{kB}$ is primarily distributed in the cytoplasm as an inactive complex bound to IkB- $\alpha$. Excess ROS produced by TNF- $\alpha$ treatment induce the phosphorylation of IKK complex, which leads to the phosphorylation of I $\mathrm{K}-\alpha$, thereby leading to the degradation of $\mathrm{I} \kappa \mathrm{B}-\alpha$ and translocation of NF- $\mathrm{kB}$ into the nucleus (Madge and Pober 2001; Zhang et al. 2009). Thus, NF-kB is an important target for designing pharmaceutical agents for interfering with the development and progression of atherosclerosis. Although mechanisms underlying HSSmediated NF- $\kappa B$ regulation are uncertain, the current study indicates that HSS suppresses NF- $\mathrm{B}$ activation by inhibiting proteolytic degradation of I $\mathrm{K} B-\alpha$ induced by TNF- $\alpha$ in HUVECs. The confocal microscopic observation indicates that HSS blocked NF- $\mathrm{kB}$ translocation into the nucleus induced by TNF- $\alpha$ in HUVECs. Therefore, these results showed the ability of HSS to suppress TNF- $\alpha$-mediated NF- $\kappa B$ activation in HUVECs. In the current study, we found that HSS treatment remarkably reduced TNF- $\alpha$-induced ROS production in HUVECs, suggesting that HSS retains strong antioxidant capacity. Hence, it is likely that the reductions of ICAM-1, VCAM-1, MCP-1, and KC expression in HUVECs are mainly related to the regulation of $N F-\kappa B$ pathway through the removal of ROS by HSS's intrinsic antioxidant activity.

Nrf2 is the primary transcription factor to regulate antioxidant proteins including $\mathrm{HO}-1$ which is an enzyme that catalyzes the degradation of heme to ferric iron, carbon monoxide, and biliverdin as reaction products. Resulting biliverdin is enzymatically converted to bilirubin by biliverdin reductase (Ayer et al. 2016). HO-1 metabolites are known to have antioxidant, anti-inflammatory, and anti-atherogenic effects (Ishikawa et al. 2001). In vitro studies show that overexpression of $\mathrm{HO}-1$ attenuates endothelial dysfunction via suppressing the production of VCAM-1, MCP-1, and macrophage stimulating factor in TNF- $\alpha$-treated vascular endothelial cells (Kawamura et al. 2005). Recent studies demonstrate that HO-1 enhances vascular protective and anti-atherogenic actions, and its expression in endothelial cells attenuates atherosclerosis (Choi et al. 2018; Kato et al. 2001). In this study, we found that HSS pretreatment markedly increased the production of HO-1 protein and mRNA which are caused by 
translocation of Nrf2 into the nucleus. Thus, enhanced HO-1 expression by HSS attributes to the removal of ROS induced by TNF- $\alpha$ treatment. This study appears to be the first finding to address characteristics of HSS in the inhibition of vascular inflammation in TNF- $\alpha$-induced HUVECs.

\section{Conclusions}

In summary, we have shown that HSS inhibits the mRNA and protein expression of adhesion molecules including ICAM-1 and VCAM-1 in TNF- $\alpha$-stimulated HUVECs. Furthermore, the vascular anti-inflammatory roles of HSS in TNF- $\alpha$-treated cells appear to be closely related to the inactivation of the NF- $\mathrm{kB}$ as well as the activation of Nrf2 pathways. Further confirmation of vascular anti-inflammatory effects of HSS and underlying mechanisms in animal models will be important for the therapeutic application of HSS for treating vascular inflammation-associated diseases.

\section{Acknowledgements}

This work was supported by a Research Grant of Pukyong National University (2017)

\section{Authors' contributions}

WGG carried out the experiments and participated to write the manuscript. SGL and JIK corrected the manuscript. YMK and SBK analyzed the content of meroterpenoids in HSS. HRK designed the study. All authors read and approved the final manuscript.

\section{Competing interests}

The authors declare that they have no competing interests.

\section{Publisher's Note}

Springer Nature remains neutral with regard to jurisdictional claims in published maps and institutional affiliations.

\section{Author details}

${ }^{1}$ Department of Food Science and Nutrition, Pukyong National University, 45, Yongso-Ro, Nam-Gu, Busan 48513, Republic of Korea. ${ }^{2}$ Department of Food Technology, Pukyong National University, 45, Yongso-Ro, Nam-Gu, Busan 48513, Republic of Korea.

\section{Received: 22 November 2018 Accepted: 18 February 2019}

Published online: 06 March 2019

\section{References}

Ayer A, Zarjou A, Agarwal A, Stocker R. Heme oxygenases in cardiovascular health and disease. Physiol Rev. 2016;96:1449-508.

Azam MS, Joung EJ, Choi J, Kim HR. Ethanolic extract from Sargassum serratifolium attenuates hyperpigmentation through CREB/ERK signaling pathways in a-MSH-stimulated B16F10 melanoma cells. J Appl Phycol. 2017;29:2089-96.

Catalan U, Hazas ML, Rubio L, Fernandez-Castillejo S, Pedret A, de la Torre R, Motilva MJ, Sola R. Protective effect of hydroxytyrosol and its predominant plasmatic human metabolites against endothelial dysfunction in human aortic endothelial cells. Mol Nutri Food Res. 2015;59:2523-36.

Catapano AL, Pirillo A, Norata GD. Vascular inflammation and low-density lipoproteins: is cholesterol the link? A lesson from the clinical trials. $\mathrm{Br} J$ Pharmacol. 2017:174:3973-85.

Chen YM, Chiang WC, Lin SL, Wu KD, Tsai TJ, Hsieh BS. Dual regulation of tumor necrosis factor-a-induced CCL2/monocyte chemoattractant protein-1 expression in vascular smooth muscle cells by nuclear factor-KB and activator protein-1: modulation by type III phosphodiesterase inhibition. J Pharmacol Exp Ther. 2004;309:978-86.
Choi ES, Yoon JJ, Han BH, Jeong DH, Lee YJ, Kang DG, Lee HS. Ligustilide attenuates vascular inflammation and activates $\mathrm{Nrf} 2 / \mathrm{HO}-1$ induction and, $\mathrm{NO}$ synthesis in HUVECs. Phytomedicine. 2018;38:12-23.

De Filippo K, Henderson RB, Laschinger M, Hogg N. Neutrophil chemokines KC and macrophage-inflammatory protein-2 are newly synthesized by tissue macrophages using distinct TLR signaling pathways. J Immunol. 2008;180:4308-15.

Gwon WG, Joung EJ, Kwon MS, Lim SJ, Utsuki T, Kim HR. Sargachromenol protects against vascular inflammation by preventing TNF-a-induced monocyte adhesion to primary endothelial cells via inhibition of NF-KB activation. Int Immunopharmacol. 2017;42:81-9.

Gwon WG, Joung EJ, Shin T, Utsuki T, Wakamatsu N, Kim HR. Meroterpinoid-rich fraction of the ethanol extract from Sargassum serratifolium suppresses TNF-a-induced monocytes adhesion to vascular endothelium and vascular inflammation in high cholesterol-fed C57BL/6J mice. J Func Foods. 2018;46:384-93.

Gwon WG, Lee B, Joung EJ, Choi MW, Yoon N, Shin T, Oh CW, Kim HR. Sargaquinoic acid inhibits TNF-a-induced NF-KB signaling, thereby contributing to decreased monocyte adhesion to human umbilical vein endothelial cells (HUVECS). J Agric Food Chem. 2015:63:9053-61.

Huang W, Huang M, Ouyang H, Peng J, Liang J. Oridonin inhibits vascular inflammation by blocking NF-KB and MAPK activation. Eur J Pharmacol. 2018;826:133-9.

Huo Y, Weber C, Forlow SB, Sperandio M, Thatte J, Mack M, Jung S, Littman DR, Ley $\mathrm{K}$. The chemokine $\mathrm{KC}$, but not monocyte chemoattractant protein-1, triggers monocyte arrest on early atherosclerotic endothelium. J Clin Invest. 2001;108:1307-14.

Ishikawa K, Sugawara D, Wang X, Suzuki K, Itabe H, Maruyama Y, Lusis AJ. Heme oxygenase-1 inhibits atherosclerotic lesion formation in Idl-receptor knockout mice. Circ Res. 2001;88:506-12.

Joung EJ, Gwon WG, Shin T, Jung BM, Choi J, Kim HR. Anti-inflammatory action of the ethanolic extract from Sargassum serratifolium on lipopolysaccharidestimulated mouse peritoneal macrophages and identification of active components. J Appl Phycol. 2017;29:563-73.

Joung EJ, Lee B, Gwon WG, Shin T, Jung BM, Yoon NY, Choi JS, Oh CW, Kim HR. Sargaquinoic acid attenuates inflammatory responses by regulating NF-KB and Nrf2 pathways in lipopolysaccharide-stimulated RAW 264.7 cells. Int Immunopharmacol. 2015;29:693-700.

Kato H, Amersi F, Buelow R, Melinek J, Coito AJ, Ke BBRW, Kupiec-Weglinski JW. Heme oxygenase-1 overexpression protects rat livers from ischemia/ reperfusion injury with extended cold preservation. Am J Transplantation. 2001;1:121-8.

Kawamura K, Ishikawa K, Wada Y, Kimura S, Matsumoto H, Kohro T, Itabe H, Kodama T, Maruyama Y. Bilirubin from heme oxygenase-1 attenuates vascular endothelial activation and dysfunction. Arterioscler Thromb Vasc Biol. 2005:25:155-60.

Kim JH, Na HJ, Kim CK, Kim JY, Ha KS, Lee H, Chung HT, Kwon HJ, Kwon YG, Kim YM. The non-provitamin A carotenoid, lutein, inhibits NF-kB-dependent gene expression through redox-based regulation of the phosphatidylinositol 3kinase/PTEN/Akt and NF-KB-inducing kinase pathways: role of $\mathrm{H}_{2} \mathrm{O}_{2}$ in NF-KB activation. Free Rad Biol Med. 2008;45:885-96.

Kleinbongard P, Heusch G, Schulz R. TNFa in atherosclerosis, myocardial ischemia/reperfusion and heart failure. Pharmacol Ther. 2010;127:295-314.

Kwon M, Lim SJ, Joung EJ, Lee B, Oh CW, Kim HR. Meroterpenoid-rich fraction of an ethanolic extract from Sargassum serratifolium alleviates obesity and nonalcoholic fatty liver disease in high fat-fed C57BL/6J mice. J Func Foods. 2018;47:288-98.

Lim S, Choi AH, Kwon M, Joung EJ, Shin T, Lee SG, Kim NG, Kim HR. Evaluation of antioxidant activities of various solvent extract from Sargassum serratifolium and its major antioxidant components. Food Chem. 2019;278:178-84.

Lim S, Kwon M, Joung EJ, Shin T, Oh CW, Choi JS, Kim HR. Meroterpenoid-rich fraction of the ethanolic extract from Sargassum serratifolium suppressed oxidative stress induced by tert-butyl hydroperoxide in HepG2 cells. Mar Drugs. 2018;16:374.

Liu L, Heinrich M, Myers S, Dworjanyn SA. Towards a better understanding of medicinal uses of the brown seaweed Sargassum in traditional Chinese medicine: a phytochemical and pharmacological review. J Ethnopharmacol. 2012;142:591-619.

Madge LA, Pober JS. TNF signaling in vascular endothelial cells. Exp Mol Pathol. 2001;70:317-25.

Nallasamy P, Si H, Babu PV, Pan D, Fu Y, Brooke EA, Shah H, Zhen W, Zhu H, Liu $D$, Li Y, Jia Z. Sulforaphane reduces vascular inflammation in mice and 
prevents TNF-a-induced monocyte adhesion to primary endothelial cells through interfering with the NF-KB pathway. J Nutr Biochem. 2014;25:824-33.

Namiki M, Kawashima S, Yamashita T, Ozaki M, Hirase T, Ishida T, Inoue N, Hirata K, Matsukawa A, Morishita R, Kaneda Y, Yokoyama M. Local overexpression of monocyte chemoattractant protein-1 at vessel wall induces infiltration of macrophages and formation of atherosclerotic lesion: synergism with hypercholesterolemia. Arterioscler Thromb Vas Biol. 2002;22:115-20.

Oh SJ, Joung EJ, Kwon MS, Lee B, Utsuki T, Oh CW, Kim HR. Anti-inflammatory effect of ethanolic extract of Sargassum serratifolium in lipopolysaccharidestimulated BV2 microglial cells. J Med Food. 2016;19:1023-31.

Packard RR, Libby P. Inflammation in atherosclerosis: from vascular biology to biomarker discovery and risk prediction. Clin Chem. 2008;54:24-38.

Rao RM, Yang L, Garcia-Cardena G, Luscinskas FW. Endothelial-dependent mechanisms of leukocyte recruitment to the vascular wall. Circ Res. 2007:101:234-47.

Zhang H, Park Y, Wu J, Chen X, Lee S, Yang J, Dellsperger KC, Zhang C. Role of TNF-a in vascular dysfunction. Clin Sci. 2009;116:219-30.

Ready to submit your research? Choose BMC and benefit from:

- fast, convenient online submission

- thorough peer review by experienced researchers in your field

- rapid publication on acceptance

- support for research data, including large and complex data types

- gold Open Access which fosters wider collaboration and increased citations

- maximum visibility for your research: over $100 \mathrm{M}$ website views per year

At $\mathrm{BMC}$, research is always in progress.

Learn more biomedcentral.com/submissions 